NASA/TM-2000-209891, Vol. 76

NASA

Technical Report Series on the Boreal Ecosystem-Atmosphere Study (BOREAS)

Forrest G. Hall and Jaime Nickeson, Editors

Volume 76

\title{
BOREAS RSS-19 1996 CASI At-sensor Radiance and Reflectance Images
}

John Miller, York University, Ontario, Canada

Jim Freemantle, Earth Observations Laboratory, Center for Research in Earth and Space Technology (EOL/CRESTECH),

Ontario, Canada

National Aeronautics and

Space Administration

Goddard Space Flight Center

Greenbelt, Maryland 20771 
Available from:

NASA Center for AeroSpace Information

7121 Standard Drive

Hanover, MD 21076-1320

Price Code: A17
National Technical Information Service 5285 Port Royal Road Springfield, VA 22161

Price Code: A10 


\title{
BOREAS RSS-19 1996 CASI At-sensor Radiance and Reflectance Images
}

\author{
John R. Miller, Jim R. Freemantle
}

\section{Summary}

The BOREAS RSS-19 team collected CASI images from the Chieftain Navaho aircraft in order to observe the seasonal change in the radiometric reflectance properties of the boreal forest landscape. CASI was deployed as a site-specific optical sensor as part of BOREAS. The overall objective of the CASI deployment was to observe the seasonal change in the radiometric reflectance properties of the boreal forest landscape. In 1996, image data were collected with CASI on 15 days during a field campaign between 18-July and 01-August, primarily at flux tower sites located at study sites near campaign between 18-July and
Thompson, Manitoba, and Prince Albert, Saskatchewan. A variety of CASI data collection strategies
were to meet the following scientific objectives: 1) canopy bidirectional reflectance, 2) canopy biochemistry, 3) spatial variability, and 4) estimates of up and downwelling PAR spectral albedo, as well as changes along transects across lakes at the southern site and transects between the NSA and SSA. The images are stored as binary image files.

Note that the 1996 CASI image data are not contained on the BOREAS. CD-ROM set. Inventory listing files are supplied on the CD-ROM to inform users of the data that were collected. See Sections 15 and 16 for information about how to acquire the data. Also see Section 11.2 for notes about an anomaly found with one of the image sizes.

\section{Table of Contents}

1) Data Set Overview

2) Investigator(s)

3) Theory of Measurements

4) Equipment

5) Data Acquisition Methods

6) Observations

7) Data Description

8) Data Organization

9) Data Manipulations

10) Errors

11) Notes

12) Application of the Data Set

13) Future Modifications and Plans

14) Software

15) Data Access

16) Output Products and Availability

17) References

18) Glossary of Terms

19) List of Acronyms

20) Document Information 


\section{Data Set Overview}

\subsection{Data Set Identification \\ BOREAS RSS-19 1996 CASI At-sensor Radiance and Reflectance Images}

\subsection{Data Set Introduction}

The Compact Airborne Spectrographic Imager (CASI) was deployed as a site-specific optical sensor as part of the BOReal Ecosystem-Atmosphere Study (BOREAS). The overall objective of the CASI deployment was to observe the seasonal change in the radiometric reflectance properties of the boreal forest landscape. Image data were collected with CASI on 15 days during the second Intensive Field Campaign (IFC) in 1996 between 18-July and 01-August. Data were collected primarily at flux tower sites located within the Northern Study Area (NSA) near Thompson, Manitoba, and the Southern Study Area (SSA) near Prince Albert, Saskatchewan. A subset of the data is available from the BOREAS Information System (BORIS).

This BORIS subset contains one spatial image per tower site per IFC per study area. All the data have been collected at approximately $1500 \mathrm{~m}$ Above Ground Level (AGL). The images have been geocorrected using onboard Global Positioning System (GPS) data. Data have been resampled to 2 meter square pixels. Radiance and at-ground modeled reflectance images have been provided. This subset of CASI-processed data corresponds to the data for CASI Mission 3 described in Section 5.

\subsection{Objective/Purpose}

CASI was used to generate reflectance images from radiance images collected during the July to August 1996 time period. These images will be used along with Airborne Visible and Infrared Imaging Spectrometer (AVIRIS), Special Sensor Microwave/Imager (SSM/I), Landsat Thematic Mapper (TM), Geostationary Operational Environmental Satellite (GOES), Advanced Very High Resolution Radiometer (AVHRR) and Satellite Pour l'Observation de la Terre (SPOT) images to determine: (i) image-based methods to obtain surface reflectances from airborne optical imagery; (ii) the effect of temporal/spatial variability of site albedo of the boreal forest; (iii) the role of seasonal changes in understory components to changes in reflectance of open boreal canopies; and (iv) the seasonal/temporal variation in closed canopy reflectance as a function of canopy architecture, species composition, canopy biophysical parameters of Leaf Area Index (LAI) and biomass, and phenologic development and chemistry of foliar components.

\subsection{Summary of Parameters}

Radiance and at-ground modeled reflectance images.

\subsection{Discussion}

Image data were collected with CASI during 15 days of IFC-2 between 18-Jul and 01-Aug-1996. Data were collected primarily at flux tower sites located within the NSA near Thompson, Manitoba, and the SSA near Prince Albert, Saskatchewan.

In order to aid our BOREAS team collaborators in locating additional information pertaining to the Canadian optical remote sensing component of the BOREAS project, a BOREAS Global Hypermedia Research Information System (B/GHRIS) is under construction at York University/Centre for Research in the Earth and Space Technology (CRESTech) (Dunlop and Shepherd, 1995). It uses World Wide Web (WWW) software to allow collaborators to search, browse, and retrieve distributed network-accessible documents. Radiometrically and/or spatially subsampled CASI images are provided for browsing directly at the collaborator's site. Other information describing the sensors, sensor deployment, flight lines, calibration, field campaigns, field data, calendar of events, bibliography and more are all now available online at http://www.eol.crestech.ca/, providing up-to-date status on CASI data processing and data delivery to BORIS and collaborators. 


\subsection{Related Data Sets}

BOREAS RSS-02 Level-1b ASAS Imagery: At-sensor Radiance in BSQ Format BOREAS RSS-18 Level-1B AVIRIS Imagery: At-sensor Radiance in BIL Format BOREAS RSS-19 1994 CASI At-sensor Radiance and Reflectance Images BOREAS Level-2 MAS Imagery: Reflectance and Temperatures in BSQ Format BOREAS Level-2 NS001 TMS Images: Reflectance and Temperatures in BSQ Format

\section{Investigator(s)}

\subsection{Investigator(s) Name and Title}

Dr. John R. Miller

\subsection{Title of Investigation}

Variation in Radiometric Properties of the Boreal Forest Landscape as a Function of the Ecosystem Dynamics

\subsection{Contact Information}

\section{Contact 1:}

Jim R. Freemantle

Project Scientist

Earth Observations Laboratory

Center for Research in Earth and Space Technology

4850 Keele St.

North York, Ontario

Canada M3J 3K1

(416) 665-5405

(416) 665-2032 (fax)

freemant@eol.crestech.ca

\section{Contact 2:}

Dr. John R. Miller

Dept. of Physics and Astronomy

York University

4700 Keele St.

North York, Ontario

Canada M3J 3K 1

(416) $736-2100 \times 77729$

(416) 736-5626 (fax)

miller@eol.crestech.ca

\section{Contact 3:}

Jaime Nickeson

Raytheon ITSS

NASA GSFC

Code 923

Greenbelt, MD 20771

(301) 286-3373

(301) 286-0239 (fax)

Jaime.Nickeson@gsfc.nasa.gov 


\section{Theory of Measurements}

A more complete discussion of the theory behind the measurements can be found in Miller et al., 1995. A short summary is presented here.

The CASI sensor is an airborne imaging spectrometer sensor with flexible operational characteristics. It was determined that three CASI operating modes and nine specific mission plans were needed to for 1996. The three operating modes were:

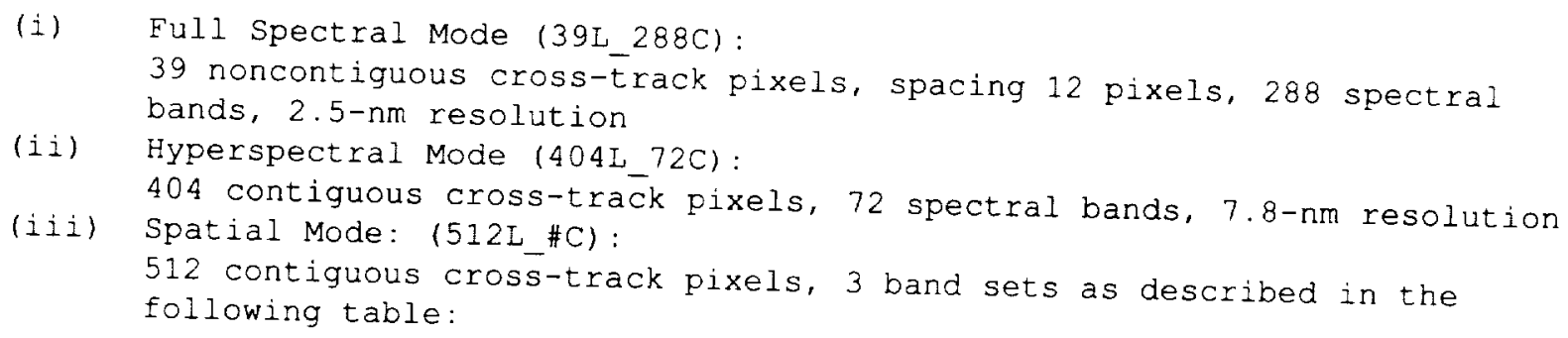

\begin{tabular}{ccc}
\multicolumn{3}{c}{ CASI-BOREAS } \\
Ch. Meris) \\
\hdashline$\quad$ Center & Bandwidth \\
\hline 1 & 410.53 & 10.34 \\
2 & 442.20 & 10.38 \\
3 & 488.88 & 10.44 \\
4 & 509.46 & 10.46 \\
5 & 530.08 & 10.48 \\
6 & 560.11 & 10.52 \\
7 & 620.36 & 10.56 \\
8 & 663.84 & 10.58 \\
9 & 681.84 & 8.70 \\
10 & 705.56 & 10.62 \\
11 & 754.10 & 8.72 \\
$12 \star$ & 758.87 & 3.00 \\
$13 *$ & 763.64 & 4.90 \\
14 & 775.10 & 12.56 \\
15 & 864.29 & 10.66 \\
16 & 889.35 & 10.66 \\
$17 \star$ & 899.01 & 10.66
\end{tabular}

Table 1: CASI Spatial Bandsets Used during BOREAS 96, units are nm. Channels marked with * have not been included in BORIS reflectance image submission. 


\section{Equipment}

\subsection{Instrument Description}

The CASI instrument (Itres, 1992) is composed of 10 components weighing a total of $55 \mathrm{~kg}$. The components of the sensor system augmented at CRESTech and as deployed at BOREAS consist of:

- Instrument Control Unit

- Keyboard Unit

- Power Supply Unit

- Sensor Head Unit

- Video Display Unit

- 60-Hz Inverter

- Downwelling Irradiance Probe

- Upwelling Irradiance Probe

- Zenith Sky Probe

- Fiber-Optic Switch Box

The Charge Coupled Device (CCD) sensor is a P86520 series frame transfer device (EEV, Inc., Chelmsford, UK). The array is thermoelectrically cooled to reduce dark current. The imaging area of the array is $512 \times 288$ pixels with each element measuring 15.5 by $22 \mu \mathrm{m}$. The instrument can be run on 110 volts at 2.4 amps. For Direct Current (DC) operation, the inverter supplied with the system requires $28 \mathrm{VDC}, 13 \mathrm{amps}$ peak. For the optional gyro, another inverter supplies $400-\mathrm{Hz}$ Alternating Current (AC).

The 512 image pixels across the field of view (FOV) of 37.7 degrees give a 1.23-meter ground resolution (cross-track) per $1 \mathrm{~km}$ AGL altitude. The along-track ground resolution is approximately the product of the integration time and the aircraft speed. The required integration time is directly proportional to the number of spectral bands and the number of spatial views. The spectral range of the CASI instrument used in the 1996 BOREAS project was 405 to $960 \mathrm{~nm}$. The spectral resolution was 2.5-nm full width, half maximum (FWHM), with 288 pixels sampled at 1.8 -nm intervals. The $2.5-\mathrm{nm}$ FWHM is nominal; the bandwidth changes with wavelength (Achal, 1991). Measurements of the bandwidth of the CASI used for BOREAS have been taken at CRESTech and are being analyzed. Channel-to-wavelength registration is subject to slight deviations at large view angles because of spectral sag (Harron et al., 1992; Freemantle et al., 1991).

The CCD sensor is read out and digitized to 12 bits by a programmable electronics system that is controlled by an internal single-board computer. Data are recorded on built-in dual digital recorders (Exabyte) that use 8-mm videocassettes as the recording medium. The frame rate is configuration-dependent up to a maximum of 85 lines/sec. The CCD can be read out to select and sum rows, to create high spatial resolution bands, or sample columns from the array, to create high spectral resolution views. The CCD sampling configuration can be easily changed by the CASI instrument operator and often several different sampling configurations are used during a data collection experiment. Additional information about the CASI sensor can be obtained from Itres instruments (http://www.itres.com/).

To collect additional information to correct at-sensor radiance to at-ground reflectance, and to monitor the temporal stability of the incident illumination, upwelling and downwelling irradiance probes were mounted in the top and bottom of the aircraft. In 1994, the probe signals were multiplexed onto a single optical fiber by a mechanical optical switching device. This single fiber is connected to the imaging slit of the CASI. In 1996, two such slit probes were installed at the CASI sensor head to enable the downwelling irradiance to be monitored without multiplexing. The data from the probes appear as additional pixels on the imager CCD. Software is used to demultiplex the probe signals.

\subsubsection{Collection Environment}

Data were collected at various altitudes from $150 \mathrm{~m}$ AGL to $2600 \mathrm{~m}$ AGL. The CASI sensor can be tilted forward or aft of the aircraft. Data have been collected at a number of different sensor pitch angles for investigations of Bidirectional Reflectance Distribution Function (BRDF) effects. Several CCD sampling configurations were used to collect imagery. Imagery has been collected at the tower 
flux sites and auxiliary sites, and along the transect between Prince Albert, Saskatchewan, and
Thompson, Manitoba.

\subsubsection{Platform}

The CASI sensor was flown aboard the Chieftain Navaho aircraft operated by the Ontario Provincial Remote Sensing Office (PRSO). Data were collected at various altitudes from $150 \mathrm{~m} \mathrm{AGL}$
to $2600 \mathrm{~m}$ AGL.

\subsubsection{Mission Objectives}

The complete set of mission objectives for the RSS-19 study is listed below. Note that only Mission 3 data have been submitted as part of the BOREAS archive data set. Contact the Principal Investigator (PI) or see the CASI Web page for availability of other mission data.

\section{CASI Missions:}

Mission 1: Flux Tower Sites: Multiview Canopy Bidirectional Reflectance Data

CASI Operating Mode: Spatial Mode (512_16C)

Pixel: 2 × $2.6 \mathrm{~m}$

Nadir Swath: $1000 \mathrm{~m}$

CASI multiband imagery in 16 channels was collected over each site at $1525 \mathrm{~m}$ altitude AGL for at least 2 different azimuth angles with respect to the solar plane and at multiple sensor view angles in order to characterize the seasonal changes in the bidirectional reflectance properties of each flux-tower forest stand. Wherever possible, CASI data were collected coincident with data from the Advanced Solid-State Array Spectroradiometer (ASAS) sensor National Aeronautics and Space Administration (NASA) Goddard Space Flight Center (GSFC) onboard the C-130 aircraft, and over the Portable Apparatus for Rapid Acquisition of Bidirectional Observations of Land and Atmosphere (PARABOLA) field instrument NASA GSFC, both of which are specifically designed to measure surface bidirectional reflectance properties. For virtually all missions, CASI imagery was collected in the solar plane with sensor view angles at 45, 30, 15, 0, -15, and -30 degrees and at a 45-degree angle oblique to the solar plane with view angles at $+45,0,-30$ degrees. Note that these angles are with respect to the airplane axis, and will vary somewhat due to aircraft attitude. The operational goal established was to obtain overlapping multiview images of at least $200 \mathrm{~m}$ in the along-track direction, this objective demanded synchronized tow view angle changes made manually by the sensor operator, at intervals during a pass over each flux tower sighting by the aircrew and sensor tilting by the operator Thus three passes of each flux tower were requir to achieve three overlapping image views per pass.

Initial comparisons between the $\mathrm{Li}$ and $\mathrm{Strahler}$ (10) BRDF sampling described above.

SSA Old Jack Pine (OJP) site in the winter campaign are model and the CASI BRDF data for the analysis underway.

Mission 2: Flux Tower Sites: Canopy Biochemistry

CASI Operating Mode: HyperSpectral Mode (404L_72C)

Pixel: 2 x $10 \mathrm{~m}$

Swath: $1000 \mathrm{~m}$

Reflectance signatures of forest canopies at high spectral resolution in the CASI visible/near-infrared (VIS/NIR) spectral region can be related to canopy chlorophyll and nitrogen levels (e.g., Matson et al., 1994). CASI spectral mode imagery was collected at $1525 \mathrm{~m}$ AGL for this purpose over each tower site in the solar plane while viewing in the forward scatter direction at 30
degrees to minimize spectral effects of the canopy understory.

Mission 3: Flux Tower Sites: Site Mapping

CASI Operating Mode: Spatial Mode, 512_16C (or 512_6C) at high (low) altitudes
Pixel: $2 \times 2.6 \mathrm{~m}$ and $0.8 \times 1.1 \mathrm{~m}$

Swath: 1000 and $400 \mathrm{~m}$ 
CASI imagery is expected to be the highest spatial resolution optical data available in the BOREAS data base and therefore has been of particular interest to a number of collaborators for quantifying the spatial inhomogeneity of site- specific field measurements of parameters such as LAI, biomass, and canopy cover. This is of particular importance to the scaling up of boreal forest ecosystem state and process parameters using remote sensing data. For these purposes, CASI multiband (16 channels) imagery has been collected in the solar plane at $1525 \mathrm{~m}$ altitude to cover the 1-km target area around each flux tower site in one image swath at a spatial resolution of approximately $2 \mathrm{~m}$. A second set of three flights in the solar plane at $600 \mathrm{~m}$ AGL displaced from each other by $300 \mathrm{~m}$ provided CASI multiband imagery in six channels at a spatial resolution of approximately $1 \mathrm{~m}$.

Mission 4: Flux Tower Sites: Albedo

CASI Operating Mode: Spatial Mode (512_16C)

Pixel: $0.2 \times 1.7 \mathrm{~m}$

Swath: $100 \mathrm{~m}$

With the CASI sensor modifications permitting collection of up and downwelling spectral irradiance data simultaneously with the normal imagery, flights at low altitude (150 m AGL) generate a measure of the spatial variability of the spectral albedo as well as the up and downwelling Photosynthetically Active Radiation (PAR). These data will also be used to measure the ratio of radiance in the GOES visible band to the total albedo for each canopy type, thereby enabling E. Smith (RSS-14) to generate seasonal albedo maps for the entire BOREAS region from GOES imagery. These same data are of interest to J. Cihlar (Terrestrial Ecology (TE)-16) and coworkers to validate models for satellite estimates of canopy absorbed PAR.

Mission 5: Lake Image Transects

CASI Operating Modes: Meris Mode 512L_17C and Hyperspectral Mode 404L_72C Spatial Mode

Pixel: $3.2 \mathrm{~m} \mathrm{x} 3.3 \mathrm{~m}$

Swath: $1635 \mathrm{~m}$; Altitude 2500-m AGL

Hyperspectral Pixel: $3 \times 11 \mathrm{~m}$

Swath: $800 \mathrm{~m}$; Altitude: 2500 -m AGL

CASI imaging spectrometer data were collected on a transect across Lake Waskesiu and Candle

Lake at the SSA; this data collection was simultaneous with in situ water sampling and optical measurements of the above-surface and below-surface, up and downwelling spectral radiance and irradiances by R. Bukata and J. Jerome (TE-15). These combined data will be used for critical evaluation of models and algorithms to derive water constituent information such as concentrations of chlorophyll, dissolved organic content, and total suspended solids for Case 2 waters. This algorithm validation/evaluation activity is directly applicable to future satellite sensors such as Medium Resolution Imaging Spectrometer (MERIS) and Sea-viewing Wide Field-of-view Sensor (SeaWiFS).

Mission 6: Agriculture Line at SSA

CASI Operating Mode: Spatial Mode: Modis 512L_16C

Pixel: $3 \times 3 \mathrm{~m}$

Swath: $1635 \mathrm{~m}$

A transect at $2500 \mathrm{~m} \mathrm{AGL}$ was selected to characterize the agriculture to boreal forest transition in the SSA. This transect was subjected to intensive sampling by flux aircraft (Airborne Fluxes and Meteorology (AFM)-04) and was imaged with the CASI sensor in order to characterize the trends and variability in the vegetation growth.

Mission 7: Atmospheric Correction

CASI Operating Modes: Spatial Mode, 16 channels; 2 Hyperspectral Modes

Pixel: various

Swath: various

A variety of multi-altitude, multi-view CASI flights were conducted, supported by surface-based and aircraft optical depth measurements, in order to evaluate methodologies being used to correct optical airborne and satellite data from at-sensor radiance to surface reflectance. A system for acquiring 
downwelling radiance and total downwelling irradiance was installed alongside CASI on the aircraft to collect needed supplementary atmospheric optical data. These data were collected over the RSS-19 site at the Prince Albert airport which included canvas standard reflectance panels and an asphalt apron (for which BRDF characterization was conducted by RSS-19 personnel from Centre d'Applications et de Recherches en Teledetection (CARTEL), led by University of Sherbrooke researchers Dr. N.T. O'Neill and Dr. A. Royer).

\title{
4.1.4 Key Variables
}

The CASI sensor directly measures the following quantities: target at-sensor radiance, and downwelling and upwelling irradiance. The irradiance measurements are experimental and are undergoing intensive investigation at CRESTech. These data may not be available for the 1996 BOREAS campaign.

\subsubsection{Principles of Operation}

CASI is a VIS/NIR push-broom imaging spectrograph with a reflection grating and a 2-D CCD solid-state array detector. The instrument operates by looking down in a fixed direction and imaging successive lines of the scene from the platform, building a 2-D image as the platform moves forward (Anger et al., 1990). The CASI instrument has been used in a variety of applications from forest cover
mapping to pollution monitoring.

\subsubsection{Instrument Measurement Geometry}

Data were collected at various altitudes from $160 \mathrm{~m}$ AGL to $2600 \mathrm{~m}$ AGL. The CASI sensor can be tilted forward or aft of the aircraft. Data have been collected at a number of different sensor view angles from -45 to +45 degrees for investigations of BRDF effects.

\author{
4.1.7 Manufacturer of Instrument \\ Itres Instruments \\ \#155, 2635-37th Avenue N.E. \\ Calgary, Alberta, Canada \\ T1Y $5 Z 6$ \\ (403) 250-9944 \\ (403) $250-9916$ (fax)
}

\subsection{Calibration}

The CASI instrument has been calibrated in the Instrument Services Laboratory at CRESTech. A two-stage approach was used to determine the absolute and relative radiometric response of the instrument. An integrating sphere (Thomas et al., 1991) was used to determine the relative response of the CCD array. For an absolute radiometric calibration, a calibrated Spectralon reflectance panel (Labsphere) and a National Research Council (NRC) traceable calibrated lamp were used. Dark current data were taken to remove any instrument-related anomalies. A more detailed description of the calibration can be found in Harron et al. (1995), Babey and Soffer (1992), and Gray et al. (1997).

Rare gas lamps were used as narrow line sources to determine the spectral calibration of the instrument. A narrow bandwidth tiltable filter was used to determine the spectral bandpass of the instrument at selected wavelengths. The transmission of the window used during data collection was characterized at a range of view angles to enable correction of CASI data to at-aircraft radiance.

Radiance imagery is converted to at-ground measured reflectance using a variant of the $5 S$ radiative transfer code, referred to as Canadian Advanced Modified 5S (CAM5S) (O'Neill et al., 1996). This procedure allows correction of the imagery at aircraft altitudes for each pixel in the scene. This is a collaborative project between the University of Sherbrooke, the Canadian Space Agency, CRESTech, and the Canadian Centre for Remote Sensing (CCRS). Further details can be found in Gray et al.,

For an estimate of the absolute calibration error measurements of the NASA field calibration sphere were used. In June 1994, CASI collected imagery of the sphere. Analysis of these images shows that between 500 and $800 \mathrm{~nm}$, the difference between the CASI-measured value and the NASA calibration 
sphere expected value (Schafer, 1994) was less than 5\%. Only one set of radiance scale factors (or calibration coefficients) was used throughout the 1994 BOREAS field season. The calibration exercise was, however, repeated several times during 1994. If it is assumed that the calibration setup did not change, analysis of these data reveals that the CASI response characteristics did not change by more than 3\% during the time of the 1994 BOREAS project. It is expected that the result for BOREAS 1996 imagery would be the same as for 1994 .

\subsubsection{Specifications}

(As given by instrument manufacturer Itres)

Field of View: 37.8 degrees across-track, 0.076 degrees along-track

Spectral Range: $545-\mathrm{nm}$ spectral window between about 400 and $1000 \mathrm{~nm}$

Spectral Samples: 288 max at 1.9-nm intervals

Spectral Resolution: 2.2-nm FWHM@650 nm

Aperture: $\mathrm{f} / 2.8$ to $\mathrm{f} / 11.0$

Dynamic Range: 12 bits

Noise Floor: 1.4 DN

Signal to Noise Ratio: 420:1 peak

Data Throughput: $420 \mathrm{~Kb}$ or greater

Operating Modes:

Spatial Mode:

512 spatial pixels, 19 spectral band maximum

Spectral Mode:

288 spectral pixels, 101 adjacent looks

48 spectral pixels, 511 adjacent looks

Enhanced Spectral Mode

72 spectral pixels, 405 adjacent looks

Full Frame Mode:

288 spectral pixels, 512 spatial pixels

Environmental Operating Conditions:

Temperature: 5 to $40^{\circ} \mathrm{C}$ operating, -20 to $+60^{\circ} \mathrm{C}$ storage

Relative Humidity: $20 \%$ to $80 \%$ noncondensing, $10 \%$ to $90 \%$ noncondensing storage

Maximum Altitude: $3048 \mathrm{~m}$ above sea level (unpressurized)

\subsubsection{Tolerance}

None given.

\subsubsection{Frequency of Calibration}

Calibration data were collected for CASI before each IFC. While only one set of calibration data has been used to calculate the radiance scale factors, the other calibration data allow tracking of any changes in the instrument response.

\subsubsection{Other Calibration Information}

The CASI sensor viewed the NASA GSFC large integrating sphere during IFC-1 during BOREAS 1994. Also, an interagency calibration experiment was conducted at the Instrument Services

Laboratory involving CRESTech, NASA GSFC, and CCRS (Harron et al., 1995) that compared the calibration radiance sources used at these institutions. See Harron et al. (1995) for details. 


\section{Data Acquisition Methods}

The CASI sensor is an airborne imaging spectrometer sensor with flexible operational characteristics. The spectral range of the CASI instrument used in the BOREAS project was 391 to $916 \mathrm{~nm}$. The CASI sensor was flown aboard the Chieftain Navaho aircraft operated by the PRSO. Data were collected at various altitudes from $150 \mathrm{~m}$ AGL to $2600 \mathrm{~m}$ AGL. The CASI sensor can be tilted forward or aft of the aircraft. Data have been collected at a number of different sensor pitch angles for investigations of BDRF effects. Several CCD sampling configurations were used to collect imagery.

The CCD sensor is read out and digitized to 12 bits by a programmable electronics system that is controlled by an internal single-board computer. Data are recorded on a built-in digital recorder (Exabyte) that uses $8-\mathrm{mm}$ videocassettes as the recording medium. The frame rate is configuration-dependent up to a maximum of 85 lines/sec. The CCD can be read out to select and sum rows, to create high spatial resolution bands, or sample columns from the array, to create high spectral resolution views. The CCD sampling configuration can be easily changed by the CASI instrument operator, and often several different sampling configurations are used during a data collection experiment.

\section{Observations}

\subsection{Data Notes}

None given.

\subsection{Field Notes}

CASI operator comments are recorded in flight logs stored as part of the CRESTech BOREAS
CASI image data base. Examination of the incident light probe (ILP) data suggests that the atmospheric conditions varied by more than $10 \%$ but not more than $20 \%$ for the images that are part of the current
BORIS submission.

\section{Data Description}

\subsection{Spatial Characteristics}

\subsubsection{Spatial Coverage}

Imagery has been collected at the NSA and SSA tower flux sites and auxiliary sites, and along the transect between the NSA and SSA. Imagery swath width depends on acquisition aircraft altitude but is typically between $1-2 \mathrm{~km}$. Imagery swath length depends on duration of data acquisition. Over the tower sites, images are usually less than $10 \mathrm{~km}$ long. Transect images can be many tens of kms long.

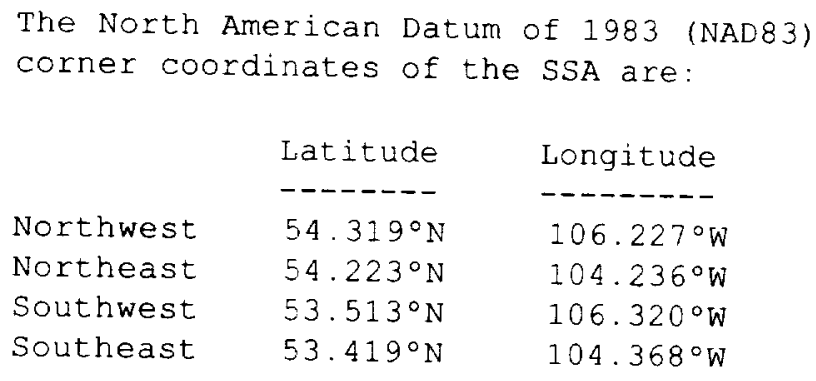


The NAD83 corner coordinates of the NSA are:

\begin{tabular}{lcr} 
& Latitude & \multicolumn{1}{c}{ Longitude } \\
& $---1 .-$ & $-1 .--$ \\
Northwest & $56.249^{\circ} \mathrm{N}$ & $98.824^{\circ} \mathrm{W}$ \\
Northeast & $56.083^{\circ} \mathrm{N}$ & $97.241^{\circ} \mathrm{W}$ \\
Southwest & $55.542^{\circ} \mathrm{N}$ & $99.045^{\circ} \mathrm{W}$ \\
Southeast & $55.379^{\circ} \mathrm{N}$ & $97.489^{\circ} \mathrm{W}$
\end{tabular}

\subsubsection{Spatial Coverage Map}

Not available.

\subsubsection{Spatial Resolution}

The 512 image pixels across the FOV of 35 degrees give a 1.23-meter ground resolution (cross-track) per $1 \mathrm{~km} \mathrm{AGL}$ altitude. The along-track ground resolution is approximately the product of the integration time and the aircraft speed. CASI image pixels are not generally square.

\subsubsection{Projection}

The imagery has been geocorrected and resampled to a Universal Transverse Mercator (UTM) grid using GPS and attitude data. This geocorrection was performed to reorient the imagery to a map grid to aid in the interpretation of the imagery. The absolute positional accuracy of the imagery should not be considered high because of the limitations of the GPS and attitude data, but the relative positional accuracy is good.

\subsubsection{Grid Description}

The CASI data supplied to BORIS have been geocorrected using the onboard GPS and attitude data. The imagery has been resampled to UTM coordinates with a square pixel size of $2.0 \mathrm{~m}$. This correction is only to aid in the interpretation and seasonal comparison of the imagery. The absolute positional accuracy of the imagery should not be considered high.

A study of the accuracy of the geocorrection methodology was undertaken using 1996 CASI data of the NSA Fen (Zarco, 1998). Targets, $30 \mathrm{~cm}$ square, were placed throughout the Fen area. The coordinates of the targets were acquired by University of Nebraska researchers R. Steinauer and D. Jelinski (Tower Flux (TF)-10) using differential GPS. A comparison of the calculated location and the measured (GPS) location of the targets showed that the absolute error was about $30 \mathrm{~m}$. The average relative error, that is, error in the distance between two points, is estimated to be about $10 \mathrm{~m}$.

\subsection{Temporal Characteristics}

\subsubsection{Temporal Coverage} Data were collected on 15 days during IFC-2 in 1996, between 18-July and 01-August.

\subsubsection{Temporal Coverage Map}

This is a table of the dates and approximate times of the data provided to BORIS. The entire CASI BOREAS image archive at CRESTech is extensive; please contact the PI or browse CRESTech's web site for a complete list of dates of CASI image acquisition (http://www.eol.crestech.ca/). 


$\begin{array}{ccc}\text { Date } & \text { Site } & \text { Approximate Time } \\ \text { (GMT) } \\ \text { 18-Jul-1996 } & \text { OA NSA } & 17: 42: 49 \\ \text { 18-Jul-1996 } & \text { OJP NSA } & 18: 12: 38 \\ 18 \text {-Jul-1996 } & \text { OBS NSA } & 18: 29: 10 \\ 18 \text {-Jul-1996 } & \text { Fen NSA } & 18: 49: 10 \\ 18-J u l-1996 & \text { YJP NSA } & 19: 09: 04 \\ \text { 20-Jul-1996 } & \text { Fen SSA } & 18: 14: 10 \\ \text { 20-Jul-1996 } & \text { OA SSA } & 19: 11: 17 \\ \text { 30-Jul-1996 } & \text { OBS SSA } & 16: 43: 03 \\ \text { 30-Jul-1996 } & \text { OJP SSA } & 17: 17: 18 \\ \text { 30-Jul-1996 } & \text { YJP SSA } & 17: 23: 50\end{array}$

\subsubsection{Temporal Resolution}

CASI imagery represents the measured instantaneous irradiance and reflected target at-sensor radiance. Frequently, multiple image acquisitions over a target were obtained during one day. On some occasions, data collections were repeated on more than one day during an IFC. Please refer to the image acquisition list available at http://www.eol.crestech.ca/.

\subsection{Data Characteristics}

\subsubsection{Parameter/Variable}

The image parameters are:

scaled radiance.

Scaled reflectance.

The parameters contained in the inventory files on the CD-ROM for CASI At-sensor Radiance and Reflectance images are:

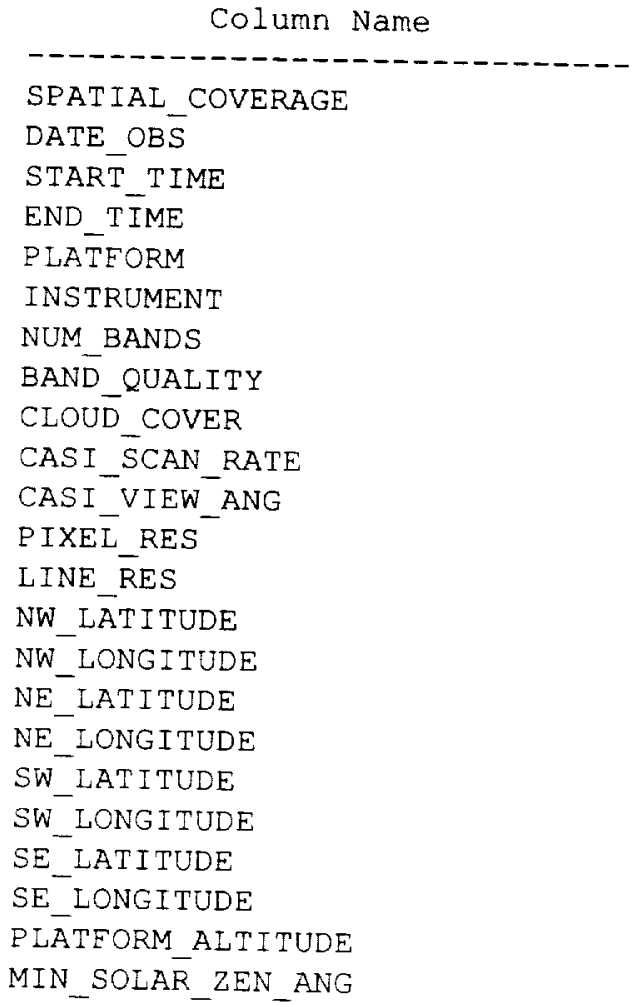


MAX_SOLAR_ZEN_ANG

MIN_SOLAR_AZ_ĀNG

MAX_SOLAR_AZ_ANG

CRTËCN_CODE

\subsubsection{Variable Description}

The CASI at-sensor radiance imagery pixel digital numbers represent scaled at-aircraft radiance values. The CASI reflectance imagery pixel digital numbers represent scaled at-ground reflectance values. The descriptions of the parameters contained in the inventory files on the CD-ROM for both types of imagery are:

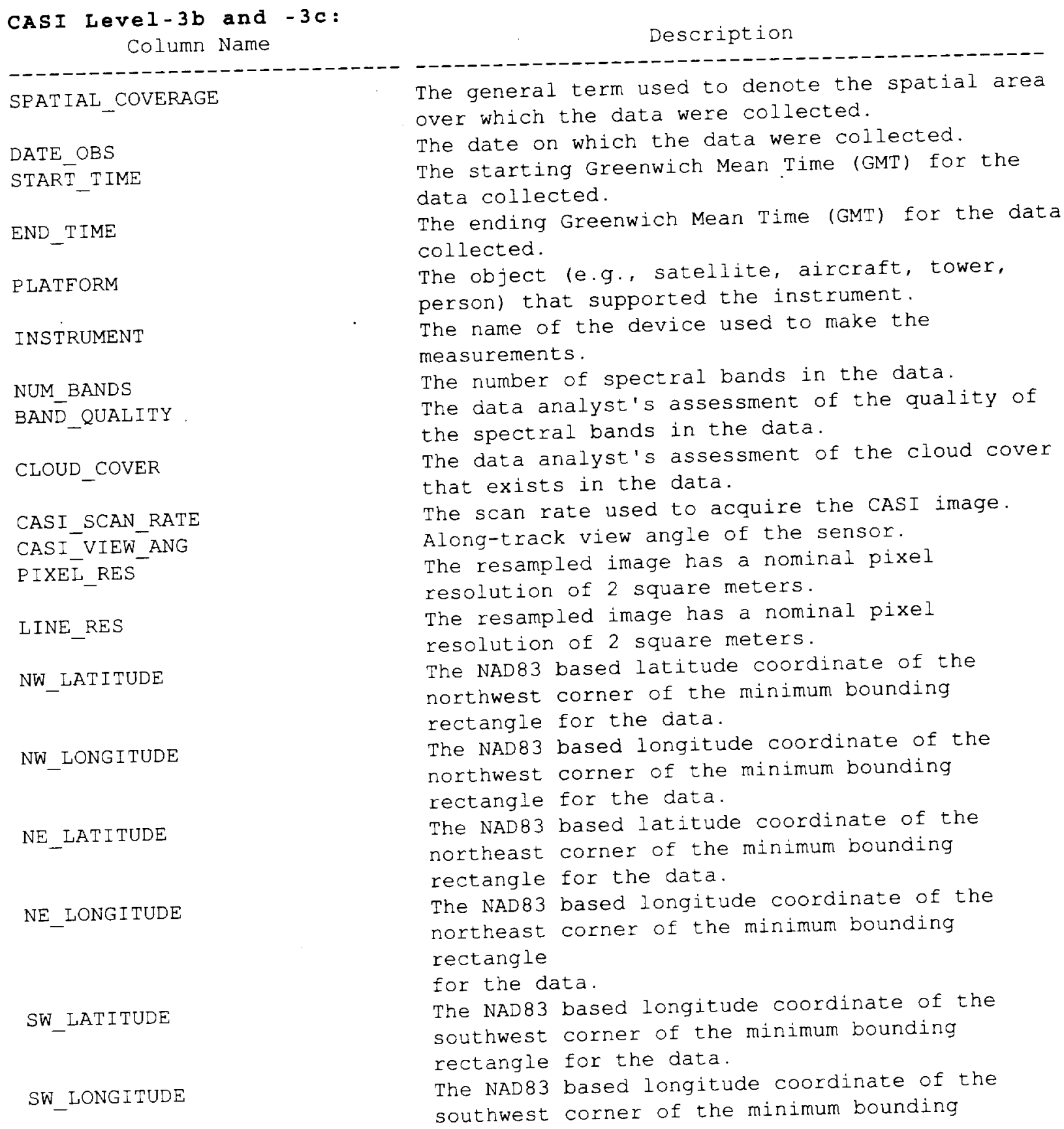




\author{
SE_LATITUDE \\ SE__LNGITUDE \\ PLATFORM_ALTITUDE \\ MIN_SOLAR_ZEN ANG \\ MAX_SOLAR_ZEN ANG \\ MIN_SOLAR_AZ_ANG \\ MAX_SOLAR_AZ_ANG \\ CRTFCN_CODE
}

rectangle for the data.

The NAD83 based longitude coordinate of the southeast corner of the minimum bounding rectangle for the data.

The NAD83 based longitude coordinate of the southeast corner of the minimum bounding rectangle for the data.

The nominal altitude of the data collection platform above the target.

The minimum angle from the surface normal (straight up) to the sun during the data collection.

The maximum angle from the surface normal (straight up) to the sun during the data collection.

The minimum azimuthal direction of the sun during data collection expressed in clockwise increments from North.

The maximum azimuthal direction of the sun during data collection expressed in clockwise increments from North.

The BOREAS certification level of the data. Examples are CPI (Checked by PI), CGR (Certified by Group), PRE (Preliminary), and CPI-??? (CPI but questionable).

\subsubsection{Unit of Measurement}

Radiance Imagery Units are Hundredths of $\mathrm{W} /\left(\mathrm{m}^{2} * \mu \mathrm{m} * \mathrm{sr}\right)$. That is, divide the scaled values by 100 to get at-sensor radiance values in $\mathrm{W} /\left(\mathrm{m}^{2} * \mu \mathrm{m} * \mathrm{sr}\right)$. Reflectance Imagery Units are $\%$ reflectance $* 500$. That is divide the scaled values by 500 to get percent reflectance values. The measurement units for the parameters contained in the inventory files on the CD-ROM for both types of imagery are:

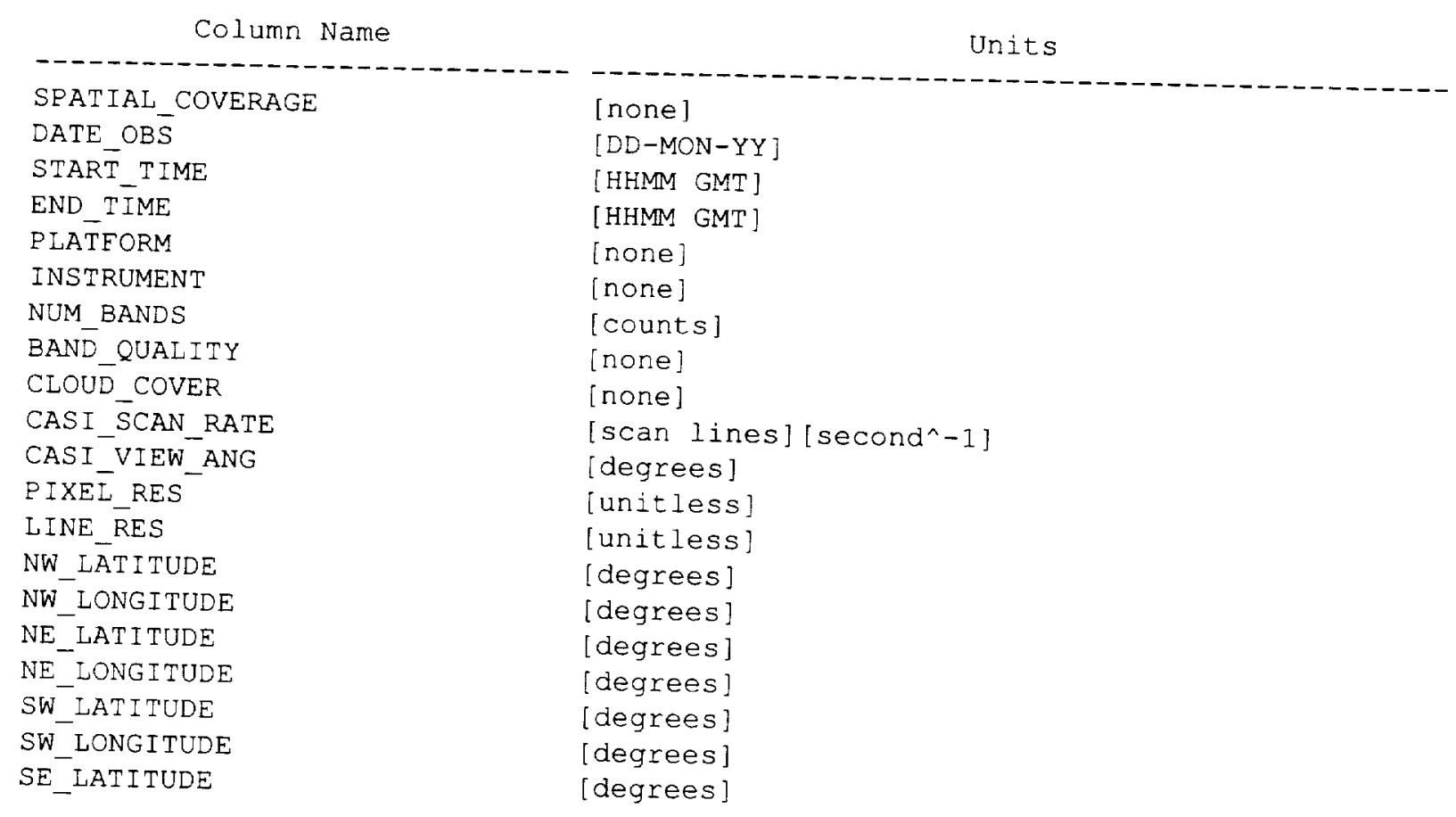

Page 14 


$\begin{array}{ll}\text { SE_LONGITUDE } & \text { [degrees] } \\ \text { PLATTFORM_ALTITUDE } & \text { [meters] } \\ \text { MIN_SOLAR_ZEN_ANG } & \text { [degrees] } \\ \text { MAX_SOLAR_ZEN_ANG } & \text { [degrees] } \\ \text { MIN_SOLAR_AZ_ANG } & \text { [degrees] } \\ \text { MAX_SOLAR_AZ_ANG } & \text { [degrees] } \\ \text { CRTFCN_CODE } & \text { [none] }\end{array}$

\subsubsection{Data Source}

The source of the CASI image data was the CASI sensor and the Center for Research in Earth and Space Technology (CRESTECH). The sources of the parameter values contained in the inventory files on the CD-ROM are:

\begin{tabular}{|c|c|}
\hline Column Name & Data Source \\
\hline & [Assigned by BORIS] \\
\hline $\begin{array}{l}\text { SPATIAL_COVERAGE } \\
\text { DATE_OBS }\end{array}$ & $\begin{array}{l}\text { [Assigned by BORIS] } \\
\text { [CASI header file] }\end{array}$ \\
\hline $\begin{array}{l}\text { DATE_OBS } \\
\text { START_TIME }\end{array}$ & $\begin{array}{l}\text { [CASI header file] } \\
\text { [CASI header file] }\end{array}$ \\
\hline $\begin{array}{l}\text { START_TIME } \\
\text { END_TIME }\end{array}$ & $\begin{array}{l}\text { [CASI header file] } \\
\text { [CASI header file] }\end{array}$ \\
\hline PLATTEORM & $\begin{array}{l}\text { [CASI header file] } \\
\text { [CASI header file] }\end{array}$ \\
\hline INSTRUMENT & $\begin{array}{l}\text { [CASI header file] } \\
\text { [CASI header file] }\end{array}$ \\
\hline NUM_BANDS & $\begin{array}{l}\text { [CASI header file] } \\
\text { [CASI header file] }\end{array}$ \\
\hline BAND_QUALITY & $\begin{array}{l}\text { [CASI header file] } \\
\text { [CASI header file] }\end{array}$ \\
\hline CLOUD_COVER & $\begin{array}{l}\text { [CASI header file] } \\
\text { [CASI header file] }\end{array}$ \\
\hline CASI_SCAN_RATE & $\begin{array}{l}\text { [CASI header file] } \\
\text { [CASI header file] }\end{array}$ \\
\hline CASI_VIEW_ANG & $\begin{array}{l}\text { [CASI header file] } \\
\text { [CASI header file] }\end{array}$ \\
\hline EIXEL_RES & $\begin{array}{l}\text { [CASI header file] } \\
\text { [CASI header file] }\end{array}$ \\
\hline LINE_RES & $\begin{array}{l}\text { [CASI header file] } \\
\text { [CASI header file] }\end{array}$ \\
\hline NW_LATITUDE & $\begin{array}{l}\text { [CASI header file] } \\
\text { [CASI header file] }\end{array}$ \\
\hline NW_LONGITUDE & $\begin{array}{l}\text { [CASI header file] } \\
\text { [CASI header file] }\end{array}$ \\
\hline NE_LATITUDE & $\begin{array}{l}\text { [CASI header file] } \\
\text { [CASI header file] }\end{array}$ \\
\hline NE_LONGITUDE & $\begin{array}{l}\text { [CASI header file] } \\
\text { [CASI header file] }\end{array}$ \\
\hline SW_LATITUDE & $\begin{array}{l}\text { [CASI header file] } \\
\text { [CASI header file] }\end{array}$ \\
\hline SW_LONGITUDE & $\begin{array}{l}\text { [CASI header file] } \\
\text { [CASI header file] }\end{array}$ \\
\hline SE_LATITUDE & $\begin{array}{l}\text { [CASI header file] } \\
\text { [CASI header file] }\end{array}$ \\
\hline SE_LONGITUDE & $\begin{array}{l}\text { [CASI header file] } \\
\text { [CASI header file] }\end{array}$ \\
\hline PLATFORM_ALTITUDE & $\begin{array}{l}\text { [CASI header file] } \\
\text { [CASI header file] }\end{array}$ \\
\hline MIN_SOLAR_ZEN_ANG & $\begin{array}{l}\text { [CASI header file] } \\
\text { [CASI header file] }\end{array}$ \\
\hline MAX_SOLAR_ZEN_ANG & $\begin{array}{l}\text { [CASI header file] } \\
\text { [CASI header file] }\end{array}$ \\
\hline MIN_SOLAR_AZ_ANG & $\begin{array}{l}\text { [CASI header file] } \\
\text { [CASI header file] }\end{array}$ \\
\hline MAX_SOLAR_AZ_ANG & $\begin{array}{l}\text { [CASI header file] } \\
\text { [CASI header file] }\end{array}$ \\
\hline CRTECN_CODE & $\begin{array}{l}\text { [CASI header file] } \\
\text { [Assigned by BORIS] }\end{array}$ \\
\hline & \\
\hline
\end{tabular}

\section{Page 15}




\subsubsection{Data Range}

The digital numbers will range from $0-65,536$. The following table gives information about the
parameter values found in the inventory files on the CD-ROM.

\begin{tabular}{|c|c|c|c|c|c|c|}
\hline \multirow[t]{3}{*}{ CASI At-sensor } & \multicolumn{6}{|c|}{ Radiance Images: } \\
\hline & Minimum & Maximum & Missng & Unrel & Below & Data \\
\hline & Data & Data & Data & Data & Detect & Not \\
\hline Column Name & Value & Value & Value & Value & Limit & Cllctd \\
\hline$--1-----1------1$ & 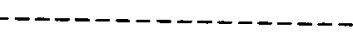 & & & & & \\
\hline SPATIAL_COVERAGE & $N / A$ & $N / A$ & None & None & None & None \\
\hline DATE_OBS & $18-J U L-96$ & $30-J U L-96$ & None & None & None & None \\
\hline START_TIME & 1643 & 1911 & None & None & None & None \\
\hline END_TIME & 1644 & 1912 & None & None & None & None \\
\hline PLATFFORM & NAVAHO CHIEFTAIN & NAVAHO CHIEFTAIN & None & None & None & None \\
\hline INSTRUMENT & $\mathrm{N} / \mathrm{A}$ & $\mathrm{N} / \mathrm{A}$ & None & None & None & None \\
\hline NUM_BANDS & 16 & 17 & None & None & None & None \\
\hline BAND_QUALITY & $\mathrm{N} / \mathrm{A}$ & $\mathrm{N} / \mathrm{A}$ & None & None & None & None \\
\hline CLOUD_COVER & $\mathrm{N} / \mathrm{A}$ & $N / A$ & None & None & None & None \\
\hline CASI_SCAN_RATE & .04 & 36.62 & None & None & None & None \\
\hline CASI_VIEW_ANG & 0 & 0 & None & None & None & None \\
\hline PIXEL_RES & 1.8 & 1.98 & None & None & None & None \\
\hline LINE_RES & 1.64 & 1.9 & None & None & None & None \\
\hline NW_LATITUDE & 53.6518 & 55.96561 & None & None & None & None \\
\hline NW_LONGITUDE & -98.70732 & -98.68373 & None & None & None & None \\
\hline NE_LATITUDE & 53.64825 & 55.95924 & None & None & None & None \\
\hline NE_LONGITUDE & -98.66098 & -98.64233 & None & None & None & None \\
\hline SW_LATITUDE & 53.5932 & 55.91401 & None & None & None & None \\
\hline SW_LONGITUDE & -98.72358 & -98.70554 & None & None & None & None \\
\hline SE_LAT ITUDE & 53.58966 & 55.90765 & None & None & None & None \\
\hline SE_LONGITUDE & -98.68114 & -98.65753 & None & None & None & None \\
\hline PLATEORM_ALTITUDE & 1767.3 & 2194.7 & None & None & None & None \\
\hline MIN_SOLAR_ZEN_ANG & 73.9 & 77.3 & None & None & None & None \\
\hline MAX_SOLAR_ZEN_ANG & 73.9 & 77.3 & None & None & None & None \\
\hline MIN_SOLAR_AZ_ANG & 149.6 & 186.4 & None & None & None & None \\
\hline MAX_SOLAR_AZ_ANG & 149.6 & 186.4 & None & None & None & None \\
\hline CRTECN_CODE & CPI & CPI & None & None & None & None \\
\hline
\end{tabular}

\section{CASI Reflectance Images:}

\begin{tabular}{|c|c|c|c|c|c|c|}
\hline Column Name & $\begin{array}{l}\text { Minimum } \\
\text { Data } \\
\text { Value }\end{array}$ & $\begin{array}{l}\text { Maximum } \\
\text { Data } \\
\text { Value }\end{array}$ & $\begin{array}{l}\text { Missng } \\
\text { Data } \\
\text { Value }\end{array}$ & $\begin{array}{l}\text { Unrel } \\
\text { Data } \\
\text { Value }\end{array}$ & $\begin{array}{l}\text { Below } \\
\text { Detect } \\
\text { Limit }\end{array}$ & $\begin{array}{l}\text { Data } \\
\text { Not } \\
\text { Cllcta }\end{array}$ \\
\hline \multicolumn{7}{|c|}{ SPATIAI GOVFRAGF } \\
\hline SPATIAL_COVERAGE & $\mathrm{N} / \mathrm{A}$ & $\mathrm{N} / \mathrm{A}$ & None & None & None & None \\
\hline DATE_OBS & $18-J U L-96$ & $30-J U L-96$ & None & None & None & None \\
\hline START_TIME & 1643 & 1911 & None & None & None & None \\
\hline END_TIME & 1644 & 1912 & None & None & None & None \\
\hline PLATFFORM & NAVAHO CHIEETAIN & NAVAHO CHIEETAIN & None & None & None & None \\
\hline INSTRUMENT & $N / A$ & $N / A$ & None & None & None & None \\
\hline NUM_BANDS & 14 & 14 & None & None & None & None \\
\hline BAND_QUALITY & $N / A$ & $N / A$ & None & None & None & None \\
\hline CLOUD_COVER & $N / A$ & $N / A$ & None & None & None & None \\
\hline CASI_SCAN_RATE & .04 & 36.62 & None & None & None & None \\
\hline CASI_VIEW ANG & 0 & 0 & None & None & None & None \\
\hline
\end{tabular}




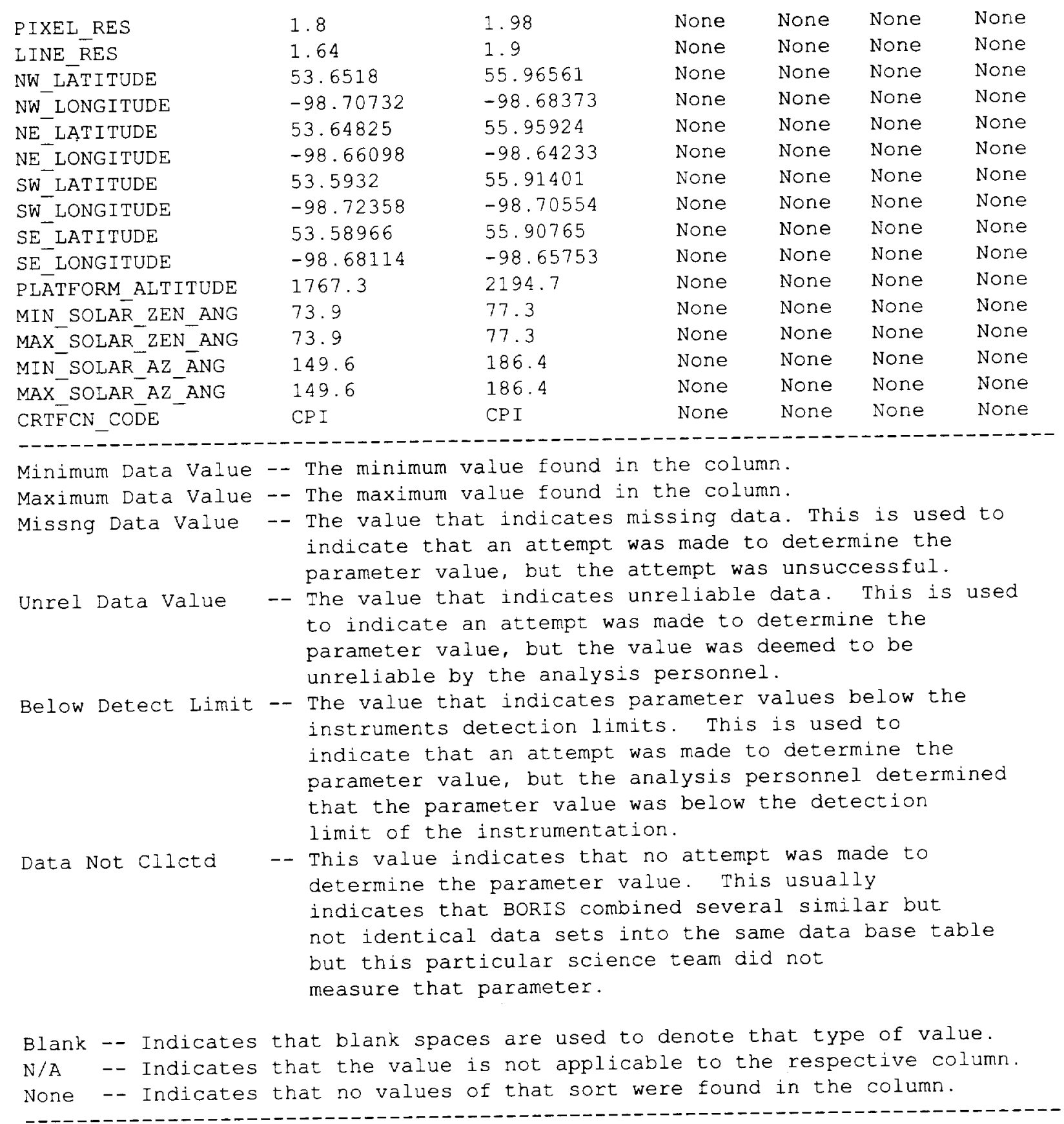




\subsection{Sample Data Record}

The following are data record from a sample data file on the CD-ROM:

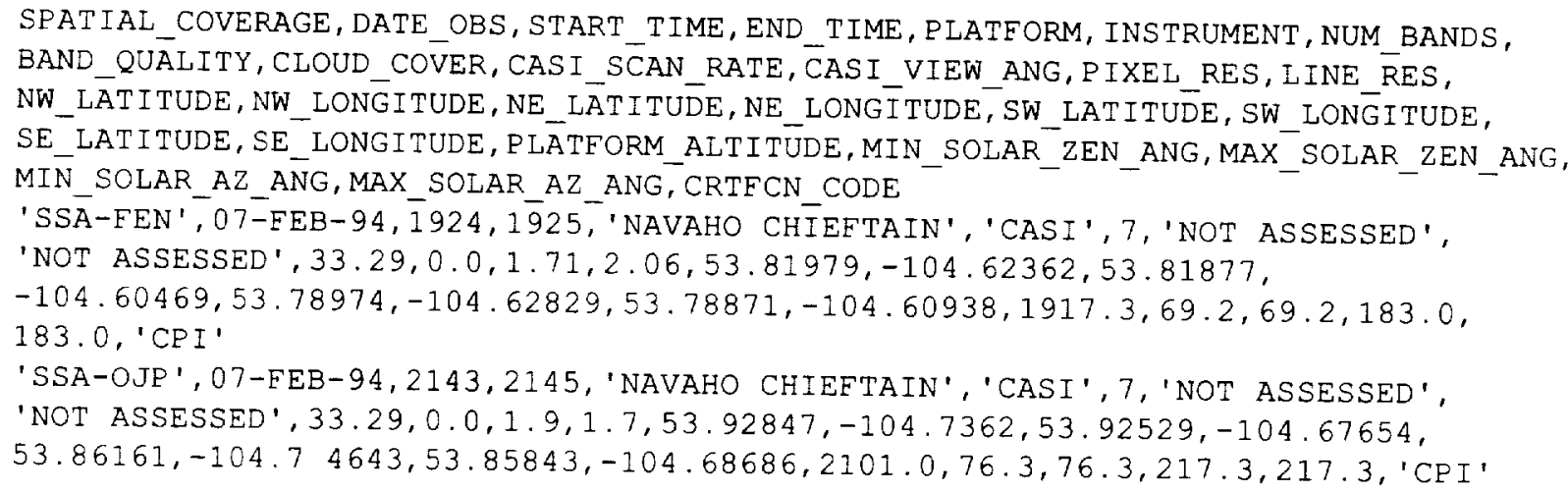

\section{Data Organization}

\subsection{Data Granularity}

The smallest unit of data tracked by BORIS is a set of 1996 at-sensor radiance or reflectance data collected at a given site on a given day.

\subsection{Data Format}

The CD-ROM inventory listing file consists of numerical and character fields of varying length separated by commas. The character fields are enclosed with single apostrophe marks. There are no spaces between the fields.

Each CASI image product consists of the following two files:

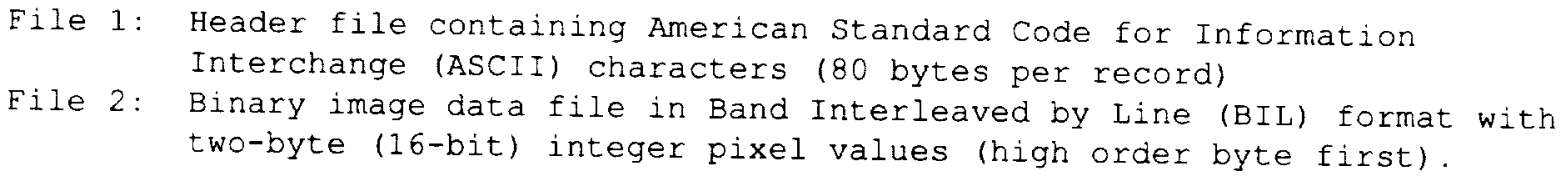

The pixel values in the image data files are stored in 2-bytes (high-order byte first). The image size and number of bands varies depending on the CASI CCD sampling configuration. The ASCII header file describes the number of pixels, bands and lines. Note that extra bytes were found at the end of the at-sensor radiance image files. This was either an artifact of the image processing package used to write the image files or it may have been due to problems noted in section 11.2. In either case we have not found that it affects the reading or importing of the data.

The following a sample CASI header file.

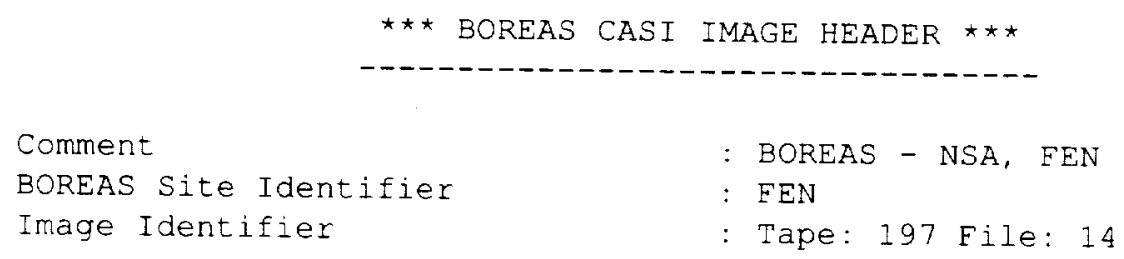


DATE AND MISSION INFORMATION

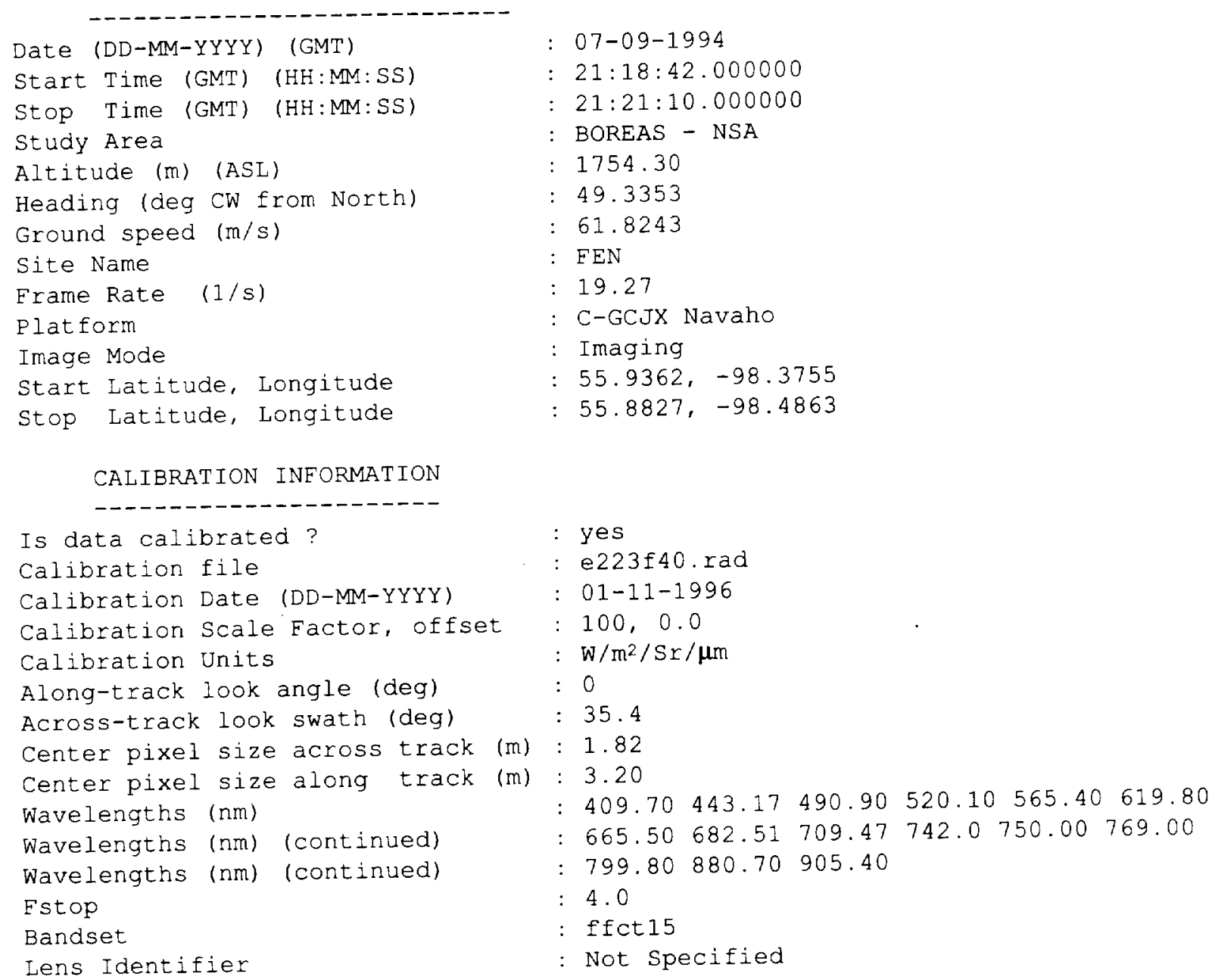

IMAGE SIZE AND FORMAT INFORMATION

\begin{tabular}{|c|c|}
\hline Number of lines original image & $: 2660$ \\
\hline Number of pixels original image & $: 512$ \\
\hline Num Iines (geocorrected image) & : 2224 \\
\hline Num pixels (geocorrected image) & : 1292 \\
\hline Num of lines offset original & $: 64$ \\
\hline Num of Iines from original & $: 2540$ \\
\hline Num of pixels offset original & $: 0$ \\
\hline Num of pixels from original & $: 512$ \\
\hline Number of bands & \\
\hline Data type & : 2 byte, big endian, integer \\
\hline Interleave mode & : BIL \\
\hline Bands Present & $: \begin{array}{lllllllllllllll}1 & 2 & 3 & 4 & 5 & 6 & 7 & 8 & 9 & 10 & 11 & 12 & 13 & 14 & 15\end{array}$ \\
\hline Tape Record Size & $: 38760$ \\
\hline Image Record Size & $:$ \\
\hline Number of Header Records & $\begin{array}{ll}: & 0 \\
. & 0\end{array}$ \\
\hline Number of Bytes / Header Record & $: 0$ \\
\hline
\end{tabular}

\section{Page 19}




\section{Data Manipulations}

\subsection{Formulae}

\subsubsection{Derivation Techniques and Algorithms}

Radiance can be derived from the formula: Rad=DN/100.

Reflectance can be derived from the formula $: \operatorname{Ref}(\%)=(\mathrm{DN} / 500)-10.0$.

\subsection{Data Processing Sequence}

\subsubsection{Processing Steps}

\section{Radiance Imagery:}

- Instrument operator's flight logs entered into imagery data base.

- Raw CASI data dumped from Exabyte tape to disc.

- Graphic Interchange Format (GIF) quicklook imagery derived from raw datato allow imagery browsing.

- GPS data extracted from CASI raw imagery. Imagery data base updated with

- GPS values for image acquisition time, altitude, heading and speed.

- CASI raw data calibrated, using radiance scale factors, to radiance.

- Output file is in PCIDSK format.

- Attitude data (Gyro) extracted from file.

- Image geocorrected using GPS and attitude data. Resampled to desired gridsize.

- PCIDSK format rewritten to BIL binary format for BORIS submission.

- $\quad$ ASCII header file created, one per imagery file.

\section{Reflectance Imagery:}

- Instrument operator's flight logs entered into imagery data base.

- Raw CASI data dumped from Exabyte tape to disc.

- GIF quicklook imagery derived from raw data to allow imagery browsing.

- GPS data extracted from CASI raw imagery. Imagery data base updated with GPS values for image acquisition time, altitude, heading, and speed.

- CASI raw data calibrated, using radiance scale factors, to radiance.

- Output file is in PCIDSK format.

- Atmospheric correction control file created using sunphotometer data and sensor geometry information.

- Radiance image (from step 5) corrected to at-ground modeled reflectance using CAM5S.

- Attitude data (Gyro) extracted from file.

- Image geocorrected using GPS and attitude data. Resampled to desired gridsize.

- PCIDSK format rewritten to BIL binary format for BORIS submission.

- ASCII header file created, one per imagery file.

\subsubsection{Processing Changes}

None.

\subsection{Calculations}

None.

\subsubsection{Special Corrections/Adjustments} None.

\subsubsection{Calculated Variables \\ None.}




\subsection{Graphs and Plots \\ None.}

\section{Errors}

\subsection{Sources of Error}

The absolute positional accuracy of the imagery should not be considered high because of limitations of the GPS and attitude data.

\subsection{Quality Assessment}

\subsubsection{Data Validation by Source}

All images submitted to BORIS have been checked to ensure that:

- All channels are saved.

- No obvious sensor anomalies exist.

- The target has been acquired.

\subsubsection{Confidence Level/Accuracy Judgment}

None given.

\subsubsection{Measurement Error for Parameters}

None given.

\subsubsection{Additional Quality Assessments}

None.

\subsubsection{Data Verification by Data Center}

BORIS staff has extracted header information and inventoried the CASI data acquisition information in the data base. BORIS staff have also viewed some of the imagery.

\section{Notes}

\subsection{Limitations of the Data}

The imagery has been geocorrected and resampled to aid in the interpretation of the imagery. The absolute positional accuracy of the imagery should not be considered high because of limitations of the GPS and attitude data.

\subsection{Known Problems with the Data}

SSA-OJP radiance image from 30-JUL-1996 17:17 GMT

Header lists 1971 rows, 1867 columns.

Correct values are 1970 rows, 1866 columns.

SSA-OJP reflectance image from 30-JUL-1996 17:17 GMT

Header lists 1971 rows, 1867 columns.

Correct values are 1970 rows, 1866 columns.

\subsection{Usage Guidance}

None given.

\subsection{Other Relevant Information}

None given. 


\section{Application of the Data Set}

These images could be used for detailed characterization of the spectral properties of the various sites. They could also be used in modeling the spectral changes that occur over the growing season.

\section{Future Modifications and Plans}

None given.

\section{Software}

\subsection{Software Description}

Software exists at CRESTech to manipulate and analyze the CASI data in the PCIDSK format. Software has been developed at CRESTech to calibrate the CASI imagery from its native tape format to calibrated radiance and then to modeled at-ground reflectance. Additional software modules can generate a 'red edge' image from the reflectance image. Other image map products are being developed. While the software works on the PCIDSK file format, the PCI EASI/PACE product is not
required.

\subsection{Software Access}

For information about available software, please contact the people named in Section 2.

\section{Data Access}

The 1996 CASI images are available from the Earth Observing System Data and Information System (EOSDIS) Oak Ridge National Laboratory (ORNL) Distributed Active Archive Center (DAAC).

\subsection{Contact Information}

For BOREAS data and documentation please contact:

ORNL DAAC User Services

Oak Ridge National Laboratory

P.O. Box 2008 MS-6407

Oak Ridge, TN 37831-6407

Phone: (423) 241-3952

Fax: (423) 574-4665

E-mail: ornldaac@ornl.gov or ornl@eos.nasa.gov

\subsection{Data Center Identification}

Earth Observing System Data and Information System (EOSDIS) Oak Ridge National Laboratory (ORNL) Distributed Active Archive Center (DAAC) for Biogeochemical Dynamics
http://www-eosdis.ornl.gov/.

\subsection{Procedures for Obtaining Data}

Users may obtain data directly through the ORNL DAAC online search and order system [http://www-eosdis.ornl.gov/] and the anonymous FTP site [ftp://www-eosdis.ornl.gov/data/] or by contacting User Services by electronic mail, telephone, fax, letter, or personal visit using the contact
information in Section 15.1. 


\subsection{Data Center Status/Plans}

The ORNL DAAC is the primary source for BOREAS field measurement, image, GIS, and hardcopy data products. The BOREAS CD-ROM and data referenced or listed in inventories on the CD-ROM are available from the ORNL DAAC.

\section{Output Products and Availability}

\subsection{Tape Products}

CASI image data are available on 8-mm tape media.

\subsection{Film Products}

None.

\subsection{Other Products}

Although the inventory is contained on the BOREAS CD-ROM set, the actual CASI images are not. See Section 15 for information about how to obtain the data.

Color GIF images of the BORIS subset are available. Additional imagery has been acquired; please browse the data base of quicklook images on the CRESTech Web site (http://www.eol.crestech.ca/).

- GPS data.

- Gyro data.

- Upwelling and downwelling light probe data, which may become available.

\section{References}

\subsection{Platform/Sensor/Instrument/Data Processing Documentation}

Dunlop, J.D. and P. Shepherd. 1995. Building a Boreal Forest Virtual Library. DSS Technical Report (Design Document).

Itres Research, Ltd. 1992. Compact Airborne Spectrographic Imager (CASI) User Manual Revision 2.1.

\subsection{Journal Articles and Study Reports}

Achal, S. 1991. Personal Communication.

Anger, C.D., S. Mah, and S.K. Babey. 1994. Technological Enhancements to the Compact Airborne Spectrographic Imager (CASI). Proceedings of the First International Airborne Remote Sensing Conference and Exhibition, Vol. II, pp. 205-213.

Anger, C.D., S.K. Babey, R.J. Adamson. 1990. A New Approach to Imaging Spectroscopy. Imaging Spectroscopy of the Terrestrial Environment, G. Vane, Editor. Proc. SPIE 1298. pp. 72-86.

Babey, S. and R.J. Soffer. 1992. Radiometric Calibration of the Compact Airborne Spectrographic Imager (CASI). Canadian Journal of Remote Sensing (Special issue on Imaging Spectrometry), Vol. 18, No. 4, Oct. 1992, pp. 233-242.

Freemantle, J.R., J.R. Miller, and A.B. Hollinger. 1991. Improvements in Spectral Feature Extraction after Image Based Refinement of Spectral Calibration of Imaging Spectrometer Data. Proceedings of the 14th Canadian Symposium on Remote Sensing. Calgary, Alberta. pp. 347-349. 
Gray, L.H., J.R. Freemantle, P.R. Shepherd, J.R. Miller, J.W. Harron, and C.H. Hersom. 1997. Characterization and Calibration of the CASI Airborne Imaging Spectrometer for BOREAS. Canadian Journal of Remote Sensing (Special issue on BOREAS), Vol. 23, No. 2, June 1997, pp. 188-195.

Harron, J.W., J.R. Freemantle, A.B. Hollinger and J.R. Miller. 1992. Methodologies and Errors in the Calibration of a Compact Airborne Spectrographic Imager. Canadian Journal of Remote Sensing (Special issue on Imaging Spectrometry), Vol. 18, No. 4, Oct. 1992, pp. 243-249.

Harron, J.W., J.R. Freemantle, L.H. Gray, P.R. Shepherd, C.H. Hersom, J.R. Miller, and A.B. Hollinger. 1995. Radiometric calibration measures for the multi-temporal BOREAS projects: results of the inter-agency cross calibration and temporal stability of CASI responsivity. Proceedings of the 17th Canadian Symposium on Remote Sensing, 13-16 June, Saskatoon, Saskatchewan, p. 202-207.

Li, X.W. and A.H. Strahler. 1992. Geometrical-optical bidirectional reflectance modeling of the discrete crown vegetation canopy: effect of crown shape and mutual shadowing. IEEE Transactions on Geoscience and Remote Sensing, Vol. GE-30, 276-291.

Matson, P., L. Johnson, C. Billow, J.R. Miller, and R. Pu. 1994. Seasonal patterns and remote spectral estimation of canopy chemistry across the Oregon Transect. Ecological Applications, Vol. 4, pp. 280-298.

Miller, J.R., J.R. Freemantle, P.R. Shepherd, L. Gray, N. O'Neill, A. Royer, and E. Senese. 1995. Deployment of CASI to meet the Needs of BOREAS Science. Proceedings of the 17th Canadian Symposium on Remote Sensing, 13-16 June, Saskatoon, Saskatchewan, pp. 169-175.

Newcomer, J., D. Landis, S. Conrad, S. Curd, K. Huemmrich, D. Knapp, A. Morrell, J. Nickeson, A. Papagno, D. Rinker, R. Strub, T. Twine, F. Hall, and P. Sellers, eds. 2000. Collected Data of The Boreal Ecosystem-Atmosphere Study. NASA. CD-ROM.

O'Neill, N.T., A. Royer, M.N. Nguyen. 1996. Canadian Advanced Modified 5S (CAM5S). Scientific and Technical Report on the Development of a Modified Version of the H5S code which incorporates major features of the 6S code. CARTEL internal report CARTEL-1996-020, 29 pp.

O'Neill, N.T., F. Zagolski, M. Bergeron, A. Royer, J. Miller, and J. Freemantle. 1997. Atmospheric Correction Validation of CASI Images Acquired over the BOREAS Southern Study Area. Canadian Journal of Remote Sensing (Special issue on BOREAS), Vol. 23, No. 2, June 1997, pp. 143-162.

Schafer, J. 1994. Personal Communication.

Sellers, P. and F. Hall. 1994. Boreal Ecosystem-Atmosphere Study: Experiment Plan. Version 1994-3.0, NASA BOREAS Report (EXPLAN 94).

Sellers, P. and F. Hall. 1996. Boreal Ecosystem-Atmosphere Study: Experiment Plan. Version 1996-2.0, NASA BOREAS Report (EXPLAN 96).

Sellers, P., F. Hall, and K.F. Huemmrich. 1996. Boreal Ecosystem-Atmosphere Study: 1994 Operations. NASA BOREAS Report (OPS DOC 94).

Sellers, P., F. Hall, and K.F. Huemmrich. 1997. Boreal Ecosystem-Atmosphere Study: 1996 Operations. NASA BOREAS Report (OPS DOC 96). 
Sellers, P., F. Hall, H. Margolis, B. Kelly, D. Baldocchi, G. den Hartog, J. Cihlar, M.G. Ryan, B. Goodison, P. Crill, K.J. Ranson, D. Lettenmaier, and D.E. Wickland. 1995. The boreal ecosystem-atmosphere study (BOREAS): an overview and early results from the 1994 field year. Bulletin of the American Meteorological Society. 76(9):1549-1577.

Sellers, P.J., F.G. Hall, R.D. Kelly, A. Black, D. Baldocchi, J. Berry, M. Ryan, K.J. Ranson, P.M. Crill, D.P. Lettenmaier, H. Margolis, J. Cihlar, J. Newcomer, D. Fitzjarrald, P.G. Jarvis, S.T. Gower, D. Halliwell, D. Williams, B. Goodison, D.E. Wickland, and F.E. Guertin. 1997. BOREAS in 1997: Experiment Overview, Scientific Results and Future Directions. Joumal of Geophysical Research 102(D24): 28,731-28,770.

Shepherd, P.R., N.T. O'Neill, and T. Piekutowski. 1995. Analysis of downwelling and up-welling diffuser probe data to determine at-sensor irradiance fluxes. Proceedings of the 17 th Canadian Symposium on Remote Sensing, 13-16 June, Saskatoon, Saskatchewan, pp. 337-342.

Soffer, R.J., W. Wanner, J.R. Miller, and A.H. Strahler. 1995. Winter boreal forest canopy BRF results: comparisons between airborne data, laboratory simulations, and geometrical-optical model data. Proceedings of IGARSS'95, 10-14 July, Firenze, Italy.

Thomas, P.J., A.B. Hollinger, K.M. Chu, and J.W. Harron. 1991. The ISTS Array Detector Test Facility. Proceedings of the Society of Photo-Optical Instrumentation Engineers, 834, pp. 91-105.

Zarco, P. 1998. Correlations between $\mathrm{CO}_{2}$ fluxes and high spatial resolution reflectance imagery. Master of Science thesis submitted to the University of Dundee.

\subsection{Archive/DBMS Usage Documentation}

None.

\section{Glossary of Terms}

None.

\section{List of Acronyms}

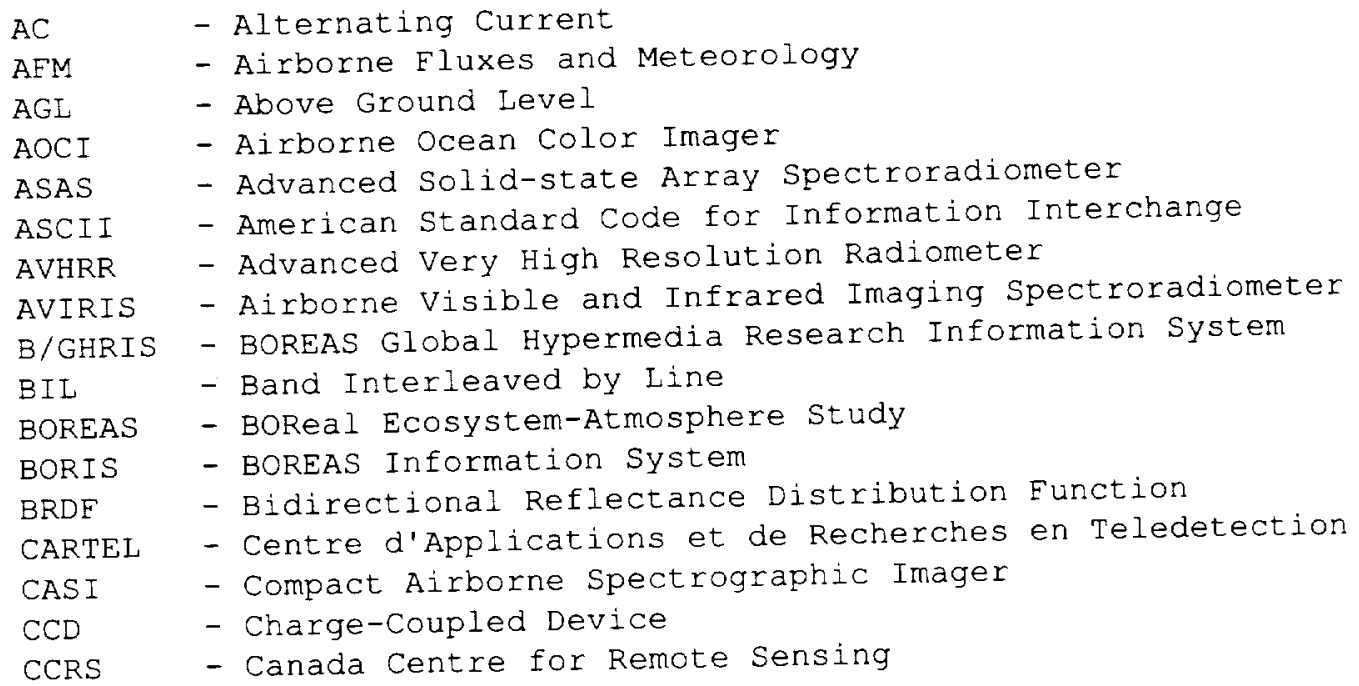




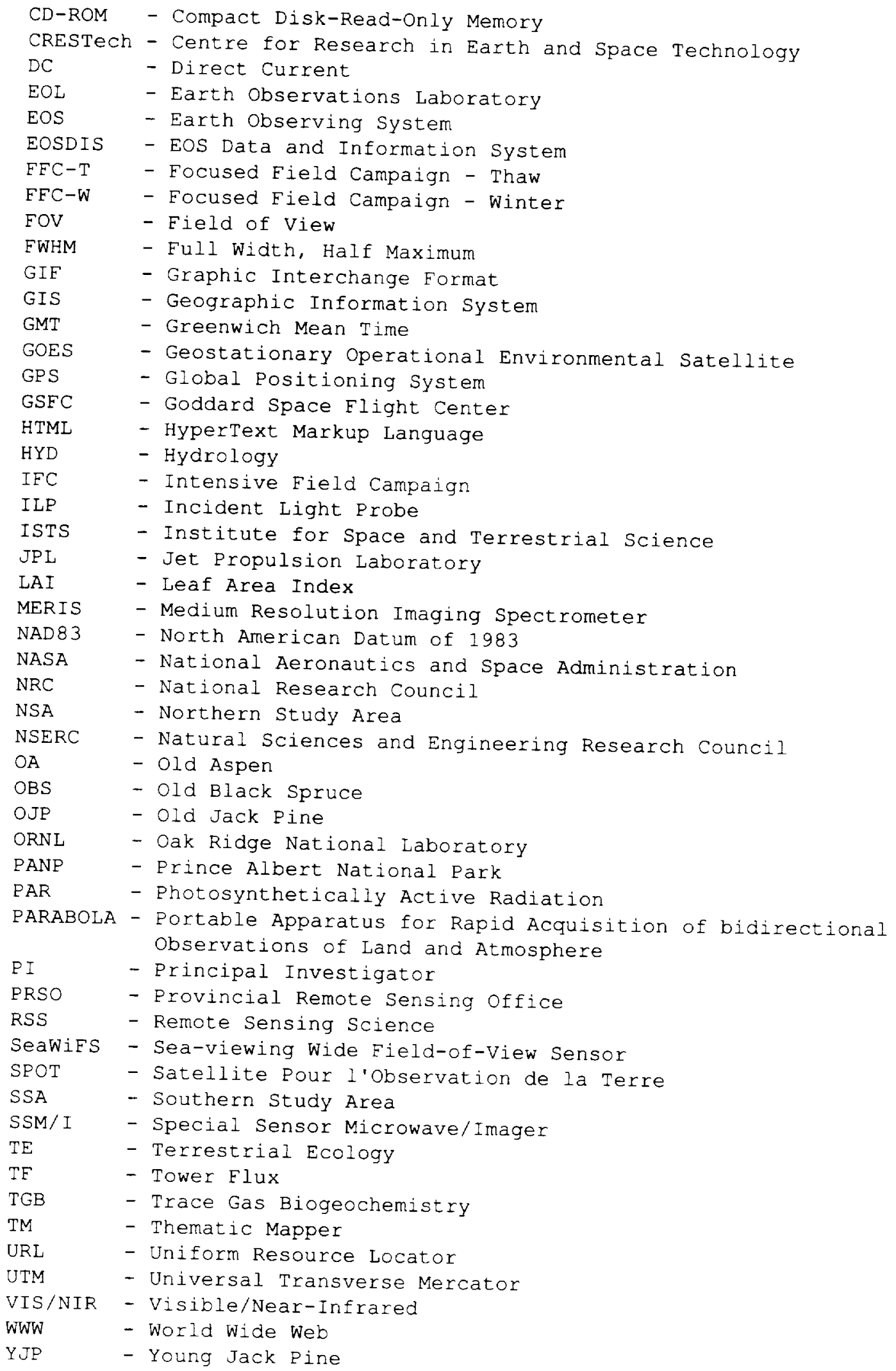

Page 26 


\section{Document Information}

20.1 Document Revision Date

Written: 07-May-1996

Last Updated: 10-Nov-1999

20.2 Document Review Date

BORIS Review: 15-Sep-1997

Science Review: 30-Jan-1998

\subsection{Document ID}

\subsection{Citation}

The CASI instrument was not supported as a facility sensor at BOREAS. The preparation, deployment, and analysis of CASI data were made possible through Natural Sciences and Engineering Research Council (NSERC) funding to the PI and funding from the Ontario Government through the Institute for Space and Terrestrial Science (ISTS), now renamed CRESTech. Users of CASI data are requested to make contact with the PI to discuss a mutually acceptable form of acknowledgment or collaboration. Acknowledgements should also include citations of relevant papers in Section 17.2.

If using data from the BOREAS CD-ROM series, also reference the data as:

Miller, J.R. "Variation in Radiometric Properties of the Boreal Forest Landscape as a Function of the Ecosystem Dynamics." In Collected Data of The Boreal Ecosystem-Atmosphere Study. Eds. J. Newcomer, D. Landis, S. Conrad, S. Curd, K. Huemmrich, D. Knapp, A. Morrell, J. Nickeson, A. Papagno, D. Rinker, R. Strub, T. Twine, F. Hall, and P. Sellers. CD-ROM. NASA, 2000.

Also, cite the BOREAS CD-ROM set as:

Newcomer, J., D. Landis, S. Conrad, S. Curd, K. Huemmrich, D. Knapp, A. Morrell, J.

Nickeson, A. Papagno, D. Rinker, R. Strub, T. Twine, F. Hall, and P. Sellers, eds. Collected Data of The Boreal Ecosystem-Atmosphere Study. NASA. CD-ROM. NASA, 2000.

\subsection{Document Curator}

\subsection{Document URL}


Public reporting burden for this collection of information is estimated to average 1 hour per response, including the time for reviewing instructions, searching existing data sources, collection of information, including suggestions for reducing and reviewing the collection of information. Send comments regarding this burden estimate or any other aspect of this Davis Highway, Suite 1204, Adington, VA 22202.4302,

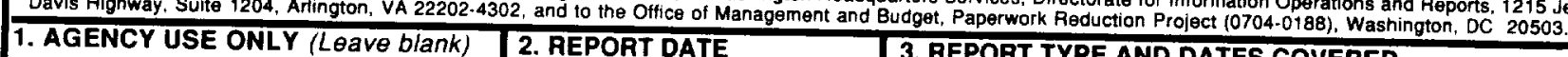
2. AEPORT DATE

August 2000 3. REPORT TYPE AND DATES COVERED

4. TITLE AND SUBTITLE Technical Memorandum

Technical Report Series on the Boreal Ecosystem-Atmosphere Study (BOREAS)

BOREAS RSS-19 1996 CASI At-Sensor Radiance and Reflectance Images

6. AUTHOR(S)

John Miller amd Jim Freemantle

Forrect G. Hall and Jaime Nickeson, Editors

7. PERFORMING ORGANIZATION NAME(S) AND ADDRESS (ES)

Goddard Space Flight Center

Greenbelt, Maryland 20771

8. PEFORMING ORGANIZATION

REPORT NUMBER

$2000-03136-0$

9. SPONSORING / MONITORING AGENCY NAME(S) AND ADDRESS (ES)

National Aeronautics and Space Administration

Washington, DC 20546-0001

10. SPONSOAING / MONTTOAING AGENCY REPORT NUMBER

TM-2000-209891

Vol. 76

\section{SUPPLEMENTARY NOTES}

J. Miller: York University, Ontario, Canada; J. Freemantle: EOL/CRESTECH, Ontario, Canada; J. Nickeson: Raytheon ITSS

128. DISTRIBUTION / AVAILABILITY STATEMENT

Unclassified-Unlimited

12b. DISTRIBUTION CODE

Subject Category: 43

Report available from the NASA Center for AeroSpace Information,

7121 Standard Drive, Hanover, MD 21076-1320. (301) 621-0390.

\section{ABSTRACT (Maximum 200 words)}

The BOREAS RSS-19 team collected CASI images from the Chieftain Navaho aircraft in order to observe the seasonal change in the radiometric reflectance properties of the boreal forest landscape. CASI was deployed as a site-specific optical sensor as part of BOREAS. The overall objective of the CASI deployment was to observe the seasonal change in the radiometric reflectance properties of the boreal forest landscape. In 1996, image data were collected with CASI on 15 days during a field campaign between 18-July and 01-August, primarily at flux tower sites located at study sites near Thompson, Manitoba, and Prince Albert, Saskatchewan. A variety of CASI data collection strategies were used to meet the following scientific objectives: 1) canopy bidirectional reflectance, 2) canopy biochemistry, 3) spatial variability, and 4) estimates of up and downwelling PAR spectral albedo, as well as changes along transects across lakes at the southern site and transects between the NSA and SSA. The images are stored as binary image files.

14. SUBJECT TERMS

BOREAS, remote sensing science, CASI.

15. NUMBER OF PAGES 27

16. PRICE CODE

17. SECURITY CLASSIFICATION OF REPORT

Unclassified

18. SECURITY CLASSIFICATION OF THIS PAGE Unclassified

NSN 7540-01-280-5500
19. SECURITY CLASSIFICATION OF ABSTRACT Unclassified
20. LIMITATION OF ABSTRACT

UL 

